\title{
One-pot reductive cyclization to antitumor quinazoline precursors
}

\author{
Sandip K. Kundu, ${ }^{\text {a }}$ Mathew P. D. Mahindaratne, ${ }^{\text {a }}$ Maritza V. Quintero, ${ }^{\text {a }}$ Ande Bao, \\ and George R. Negrete ${ }^{a^{*}}$ \\ ${ }^{a}$ Department of Chemistry, University of Texas at San Antonio, One UTSA Circle, San Antonio, \\ TX 78249, USA \\ ${ }^{b}$ Department of Radiology, University of Texas Health Science Center at San Antonio, San \\ Antonio, TX 78229, USA \\ E-mail: george.negrete@utsa.edu
}

\begin{abstract}
A highly efficient and versatile synthetic approach to the central core of anti-cancer quinazolinone derivatives is reported. Intermolecular reductive $N$-heterocyclizations of various 2-nitrobenzoic acid derivatives with formamide were catalyzed by indium(III) or bismuth(III) salts to yield the title compounds in high yields and excellent purities. In the present one-pot sequence, the arylnitro group is apparently reduced by formamide decomposition product carbon monoxide and the resultant anthranilic acid derivative proceeds to Niementowski cyclocondensation to form quinazolinones. The transformation is robust for diverse substituents on the aryl group and In(III) counterions, and is also compatible with $\mathrm{N}$-alkyl formamides but not dimethylformamide.
\end{abstract}

Keywords: Indium(III) acetate, nitro reduction, reductive heterocyclization, quinazolinone, cancer therapeutics

\section{Introduction}

Quinazoline and its derivatives are a class of heteroaromatic compounds that have drawn much attention because of their biological and pharmaceutical activities including a wide range of antitumor activity. ${ }^{1-4}$ Anilinoquinazolines in particular are potent inhibitors of Growth Factor Receptor (GFR) tyrosine kinases and have found clinical applications in Epidermal and Vascular Endothelial GFR targets (Figure 1). ${ }^{5-7}$ Among other pharmacological activities, quinazoline derivatives show remarkable antimicrobial properties against microorganisms associated with death in patients carrying immunocompromised diseases. ${ }^{8}$ We recently embarked on a program to synthesize anilinoquinazoline analogs as experimental cancer therapeutics. The preparation of

\footnotetext{
* Corresponding author. Tel.: +1-210-458-5448; fax: +1-210-458-4957; e-mail: george.negrete@utsa.edu.
} 
such targets proceeds via the intermediacy of $4(3 H)$-quinazolinone, which is also active against microorganisms. ${ }^{9-10}$ Here, we describe a streamlined and highly efficacious entry into the quinazolinone derivatives via a novel reductive heterocyclization mediated by indium(III) and bismuth(III) acetates.<smiles>COc1cc2ncnc(Nc3ccc(F)c(Cl)c3)c2cc1OCCCN1CCOCC1</smiles>

Gefitinib or ZD-1839 (Iressa ${ }^{\circledR} ;$ AstraZeneca)<smiles>C#Cc1cccc(Nc2ncnc3cc(OCCOC)c(OCCOC)cc23)c1</smiles>

Erlotinib or OSI-774 (Tarceva®i; Genentech/OSIP)<smiles>COc1cc2c(Nc3ccc(Br)cc3F)ncnc2cc1OCC1CCN(C)CC1</smiles>

Vandetanib or ZD-6474 (Zactima®; AstraZeneca)<smiles>C[SH](C)CCNCc1ccc(-c2ccc3ncnc(Nc4ccc(OCc5cccc(F)c5)c(Cl)c4)c3c2)o1</smiles>

Lapatinib or GW-572016 (Tykerb®; GlaxoSmithKline)

Figure 1. Growth Factor Receptor tyrosine kinase-targeting anti-cancer drugs.

The syntheses of quinazolinone derivatives has been accomplished by cyclocondensation of formamide with anthranilic acid derivatives (Scheme 1, route a) or the less common FriedelCrafts annulation of aminoaryl substrates (Scheme 1, route b). ${ }^{11}$ Variations of the former transformation typically proceed via a two-step sequence ${ }^{11-12}$ beginning with reduction of 2nitrobenzoate to the amino analog followed by conventional Niementowski ${ }^{11 a}$ cyclization with formamide to elaborate the quinazolinone framework. The overall yield of this route is reduced by the modest efficiencies of the reduction ( $\mathrm{Zn} /$ acetic acid, $\mathrm{SnCl}_{2} / \mathrm{HCl}$, or catalytic hydrogenation) and cyclocondensation steps, and the purifications required after each stage. In the present report, the reduction and Niementowski cyclization steps occur in a single pot without added reducing agents to provide quinazolinone products in excellent yields and purities. 


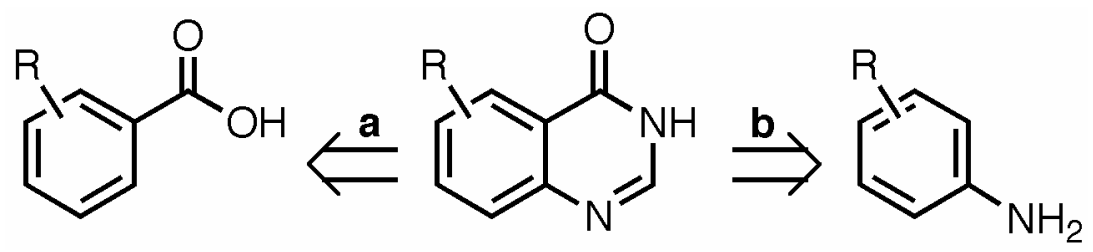

Scheme 1. Approaches to the quinazolinone framework.

\section{Results and Discussion}

Our studies required the preparation of 7-benzyloxy-6-methoxy-4(3H)-quinazolinone $(\mathbf{2} \mathbf{b}),{ }^{13}$ which had been previously formed from the reduction of benzyl 4-benzyloxy-5-methoxy-2nitrobenzoate (1b) in $\mathrm{Zn} / \mathrm{HOAc}$ followed by cyclocondensation with formamide $\left(150^{\circ} \mathrm{C} / 10 \mathrm{~h}\right)$. In our hands, the sequence gave a modest overall yield ( $42 \%$ from $1 \mathbf{b})$ due to the appreciable formation of byproducts at each step and the careful chromatographic isolations required to purify materials. Subsequent one-pot experiments that employed $\mathbf{1 b}$ and formamide in the presence of indium(III) acetate (1 equiv, $150{ }^{\circ} \mathrm{C} / 5 \mathrm{~h}$ ) yielded a single product according to the TLC and ${ }^{1} \mathrm{H}-\mathrm{NMR}$ analysis (Scheme 2). After filtration of the crude product through a plug of silica gel (ethyl acetate) $\mathbf{2 b}$ was obtained in high yield (87\%, Entry 2; Table 1). Likewise, 4(3H)quinazolinone (2a) was obtained in $89 \%$ yield (Entry 1) from benzyl 2-nitrobenzoate (1a). The purity of crude materials from the one-pot reactions in all examples in Table 1 obviated the need for chromatographic separations. ${ }^{13-14}$

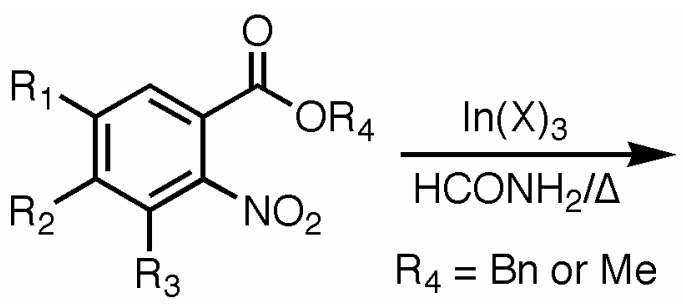

1a-1h<smiles>[R]c1cc2c(=O)[nH]cnc2c([R])c1[R]</smiles>

2a-2h

Scheme 2. Quinazolinone preparation by reductive heterocyclization.

Cognizant that a diverse set of substituted quinazolinone analogs have been employed in medicinal studies, a preliminary examination of the generality of this sequence was undertaken. The transformation was compatible with alkoxy, chloro, and thiomethyl substituents on the fused aryl ring (Entry 2-8; Table 1), each of which provided products that are intermediates in the syntheses of therapeutic analogs. ${ }^{5-7}$ For example, $\mathbf{2 b}$ is the precursor to cancer drugs ZD6474 (Vandetanib, developed by AstraZeneca under the trade name Zactima $\left.{ }^{\circledR}\right)^{15}$ and ZD4190 (currently under clinical trials; AstraZeneca) ${ }^{16}$ while $2 \mathbf{c}$ is the precursor for the potent lung 
cancer drug ZD1839 (Gefitinib, developed by AstraZeneca under the trade name Iressa $\left.{ }^{\circledR}\right) .{ }^{17} \mathrm{~A}$ comparison of the yields of this streamlined sequence with reported cyclocondensations (from anthranilic acids) are presented in the Table 1 (reported yields do not include the nitro group reductions as they are not typically reported).

Table 1. Synthesis of 4(3H)-quinazolinone derivatives from corresponding alkyl esters ${ }^{\mathrm{a}}$

\begin{tabular}{|c|c|c|c|c|c|c|c|c|}
\hline Entry & Substrate $^{b}$ & $\mathrm{R}^{1}$ & $\mathrm{R}^{2}$ & $\mathrm{R}^{3}$ & Product $^{\mathrm{b}}$ & Yield $^{c}$ & $\begin{array}{l}\text { Lit. } \\
\text { Yield }^{\mathrm{d}}\end{array}$ & $\mathrm{Mp}$ (Lit.) ${ }^{\circ} \mathrm{C}$ \\
\hline 1 & $1 \mathbf{a}$ & $\mathrm{H}$ & $\mathrm{H}$ & $\mathrm{H}$ & $2 \mathbf{a}$ & 89 & $59^{\mathrm{e}}$ & $214(215)^{\mathrm{e}}$ \\
\hline 2 & $1 b$ & $\mathrm{OMe}$ & OBn & $\mathrm{H}$ & $2 b$ & $87(83)^{\mathrm{f}}$ & $60^{\mathrm{g}}$ & $258(-)^{\mathrm{h}}$ \\
\hline 3 & $1 \mathrm{c}$ & OBn & $\mathrm{OMe}$ & $\mathrm{H}$ & $2 c$ & 83 & $65^{\mathrm{g}}$ & $252(-)^{\mathrm{h}}$ \\
\hline 4 & 1d & $\mathrm{OMe}$ & $\mathrm{OMe}$ & $\mathrm{H}$ & 2d & 78 & $65^{\mathrm{e}}$ & $262(264)^{\mathrm{e}}$ \\
\hline 5 & $1 \mathrm{e}$ & $\mathrm{OMe}$ & $\mathrm{H}$ & $\mathrm{OMe}$ & $2 \mathrm{e}$ & 71 & $37^{\mathrm{e}}$ & $281(280-282)^{\mathrm{e}}$ \\
\hline 6 & 1f & $\mathrm{OMe}$ & $\mathrm{OMe}$ & $\mathrm{OMe}$ & $2 f$ & 75 & $77^{i}$ & $229(231)^{\mathrm{j}}$ \\
\hline 7 & $1 g$ & $\mathrm{Cl}$ & $\mathrm{H}$ & $\mathrm{H}$ & $2 g$ & 79 & $68^{\mathrm{e}}$ & $264(265-267)^{\mathrm{e}}$ \\
\hline 8 & $1 \mathrm{~h}$ & $\mathrm{SMe}$ & $\mathrm{H}$ & $\mathrm{H}$ & $2 h$ & 73 & $92^{\mathrm{e}}$ & $201(203-204)^{\mathrm{e}}$ \\
\hline
\end{tabular}

${ }^{\text {a }}$ All reactions were performed in the presence of $100 \mathrm{~mol} \%$ catalyst at $150{ }^{\circ} \mathrm{C}$ and were completed within 5 hours according to TLC and 1H-NMR analyses. ${ }^{b}$ See Scheme 2 for the positions of $\mathrm{R}^{1}, \mathrm{R}^{2}$, and $\mathrm{R}^{3}$ on substrates and products. ${ }^{\mathrm{c}}$ Isolated yields after silica gel filtration and crystallization. ${ }^{\mathrm{d}}$ The yields reported are for Niementowski cyclization only. ${ }^{\mathrm{e}}$ Reference 14. ${ }^{\mathrm{f}}$ Yield of the reaction with $100 \mathrm{~mol} \% \mathrm{Bi}(\mathrm{OAc})_{3}$ in place of $\operatorname{In}(\mathrm{OAc})_{3} .{ }^{\mathrm{g}}$ Yields we obtained after following the procedure in Reference 13. ${ }^{\mathrm{h}}$ These compounds were previously reported without melting points (reference 13). ${ }^{\mathrm{i}}$ Yield from microwave assisted reaction (reference 12b). ${ }^{\mathrm{j}}$ Reference $12 b$.

The use of other 2-nitrocarboxylic acid derivatives was also examined. Thus, methyl 2nitrobenzoate, 2-nitrobenzoic acid, 2-nitrobenzamide, and 2-nitrocyanobenzene each cleanly gave product upon exposure to formamide and $\mathrm{In}(\mathrm{III})$ chloride (Table $2 ; 150{ }^{\circ} \mathrm{C} / 5 \mathrm{~h}$ ).

Table 2. Reactions of carboxylic acid and formamide derivatives

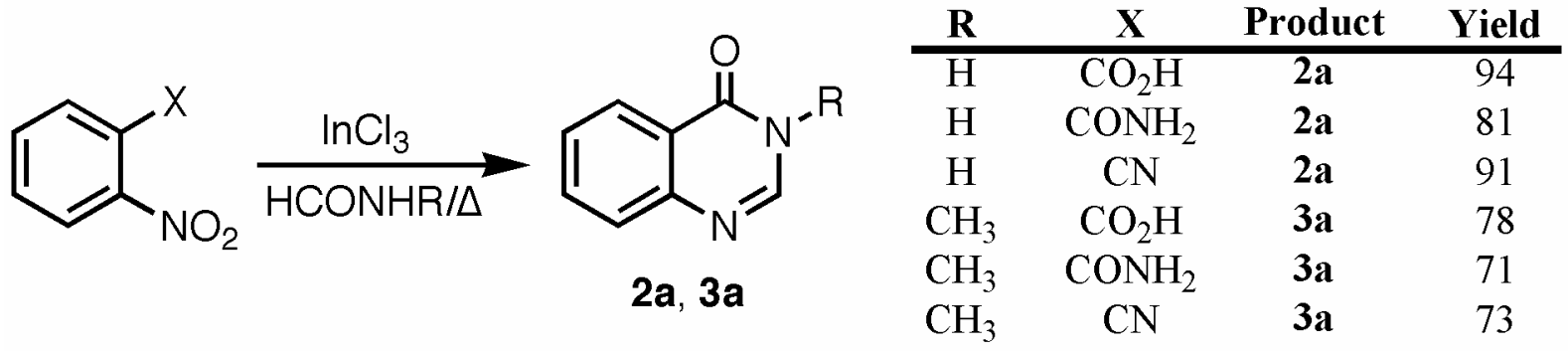


The transformation was compatible with indium(III) chloride and triflate salts, as well as bismuth(III) acetate but did not occur with the acetates of $\mathrm{Zn}^{+2}, \mathrm{Fe}^{+3}, \mathrm{Sc}^{+3}, \mathrm{Yb}^{+3}$, and $\mathrm{Ni}^{+2}$. A full equivalent of In(III) or Bi(III) salt was required for the complete conversion. The transformation did not proceed in the absence of salt even after extended heating. Only a small amount of 2a was formed when methyl 2-nitrobenzoate and formamide were reacted with $20 \mathrm{~mol} \%$ of $\mathrm{In}(\mathrm{OAc})_{3}$ or $\mathrm{InCl}_{3}\left(150^{\circ} \mathrm{C}\right)$, even after 5 days.

Several observations and experiments yielded mechanistic insights for this transformation. The reaction is likely to proceed via nitro group reduction followed by typical Niementowski cyclocondensation (Scheme 3), however the reagents used in this transformation include no obvious reductant. Carbon monoxide has been previously employed in transition metal complex ${ }^{18}$ or selenium ${ }^{19}$ catalyzed arylnitro group reductions to anilines and is also a known byproduct of formamide thermal decomposition ${ }^{20}$ at $197{ }^{\circ} \mathrm{C}^{20 \mathrm{a}}$ or at $230{ }^{\circ} \mathrm{C} .{ }^{20 \mathrm{~b}}$ To test for the decomposition of formamide under the present conditions, methyl benzoate was heated with formamide $\left(150{ }^{\circ} \mathrm{C}, 5 \mathrm{~h}\right)$ in the presence and absence of $\operatorname{In}(\mathrm{OAc})_{3}$. The observation of the quantitative formation of benzamide in the In(III) containing preparation and the lack of benzamide in the reaction not containing In(III) indicates that the metal salt catalyzes the formamide decomposition at these lower temperatures. Also, the nitro group reduction under these conditions was further examined by exposing nitrobenzene to In(III) salts (chloride or acetate, $N$-methylformamide, $150^{\circ} \mathrm{C}, 10 \mathrm{~h}$ ). The quantitative formation of aniline was observed $\left({ }^{1} \mathrm{H}\right.$ NMR), indicating the reductive potential of these conditions. In all $\mathrm{In}(\mathrm{III})-$ and $\mathrm{Bi}(\mathrm{III})-$ promoted transformations a brown, organic-insoluble solid was also recovered in place of the original white salt. An experiment in which metal salts $\mathrm{InCl}_{3}, \mathrm{In}(\mathrm{OAc})_{3}$, and $\mathrm{Bi}(\mathrm{OAc})_{3}$ were independently heated in formamide $\left(150{ }^{\circ} \mathrm{C}, 10 \mathrm{~h}\right)$ also induced the conversion of the white metal salts to dark materials (dark gray beads in the case of the bismuth salt), which suggests that $\mathrm{CO}$ reduces the metal(III) cation concurrently in this transformation. This was confirmed by the observation that the beads obtained from $\mathrm{Bi}(\mathrm{OAc})_{3}$ were capable of conducting electric current. Several experiments examined the possibility that a reduced amount of formamide might selectively reduce the arylnitro group without effecting metal cation reduction, which would enable the development of a conversion using a catalytic quantity of metal salt. Preparations with reduced amounts of formamide ( 3 or 6 equiv; 1.0 equiv $\mathrm{InCl}_{3}$ ) generated dark salts and trace amounts of quinazoline, indicating that the metal cation and arylnitro groups are reduced at similar rates. 


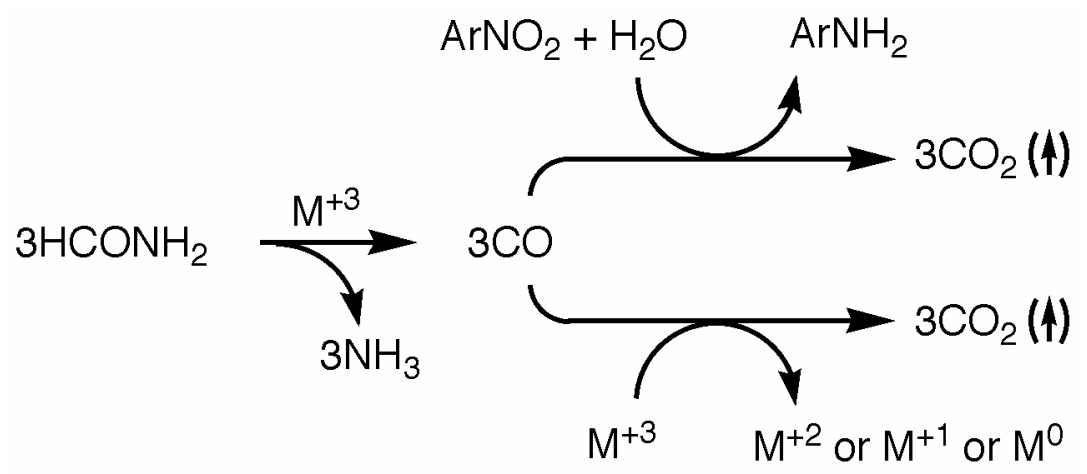

Scheme 3. Reductive cyclization by formamide.

In the present reactions metal salts promote formamide decomposition and arylnitro group conversion to arylamines, but are reduced in the reaction leading to the requirement for a full equivalent of metal salt. The metal cation might also participate in catalyzing the subsequent cyclization step, but this issue has yet to be addressed. We are continuing to search for conditions under which metal salts are preserved in this reaction, which would permit the use of metal salts in catalytic quantities to promote the preparation of quinazoline products.

\section{Conclusions}

Intermolecular reductive N-heterocyclization of 2-nitrobenzoic acid and its acid derivatives with formamide was catalyzed by indium(III) or bismuth(III) salts to yield $4(3 H)$-quinazolinones in one-pot. Product purities preclude the need for chromatographic isolation, which contrasts sharply with the purifications required in the two-step sequence. A notable feature of this transformation is the role of formamide as reductant, cyclocondensate, and solvent. These studies also establish the precedent for employing formamide/metal salts as surrogates for CO. Studies are continuing on the syntheses of quinazolinones and on mechanistic issues related to this reaction.

\section{Experimental Section}

General Procedures. Proton NMR and ${ }^{13} \mathrm{C}$ NMR spectra were recorded at $500 \mathrm{MHz}$ and 75 $\mathrm{MHz}$ (Varian Inova), respectively in DMSO- $d_{6}$ at $25^{\circ} \mathrm{C}$. Chemical shift values are reported in ppm with TMS as reference. The coupling constant $J$ values are given in Hz. The IR spectra were recorded on a BRUKER VECTOR 22 FT-IR spectrometer. Kieselgel $60 \mathrm{~F}_{254}$ silica gel TLC plates were used for monitoring reaction progress. Column chromatography was performed using silica gel-60 (TSI Scientific, 230-400 mesh) with ethyl acetate (Optima ${ }^{\circledR}$, Fisher Scientific) as solvent. All necessary chemicals were purchased from either Sigma-Aldrich (St. Louis, MO) or 
Acros (Geel, Belgium) Chemical Companies and used without purification. All the metal salts were purchased with $99 \%$ or better purity.

Substrate preparation. Benzyl 2-nitrobenzoate (1a) and benzyl 5-chloro-2-nitrobenzoate (1g) were prepared from 2-nitrobenzoic acid and 5-chloro-2-nitrobenzoic acid, respectively. Benzyl 5-thiomethoxy-2-nitrobenzoate (1h) was prepared from $\mathbf{1 g}$ using literature procedure. ${ }^{14}$ Benzyl 4-benzyloxy-5-methoxy-2-nitrobenzoate (1b; from vanillic acid), benzyl 5-benzyloxy-4methoxy-2-nitrobenzoate (1c; from isovanillic acid), benzyl 4,5-dimethoxy-2-nitrobenzoate (1d; from vanillic acid), and benzyl 3,5-dimethoxy-2-nitrobenzoate (1e; from 3,5-dimethoxybenzoic acid), were prepared according to the literature procedure. ${ }^{13}$

\section{Typical procedure for the synthesis of $4(3 H)$-quinazolinone derivative (2) in single-step reaction}

The mixture of the corresponding 2-nitrobenzoic acid derivative $\mathbf{1}(1.0 \mathrm{mmol})$ and formamide $(1.6 \mathrm{~mL}, 40 \mathrm{mmol})$ was heated at $150{ }^{\circ} \mathrm{C}$ in the presence of indium (III) salt $(1.0 \mathrm{mmol})$ and monitored by TLC. After the completion of the reaction (average time: $5 \mathrm{~h}$ ), the mixture was poured into ice-cold water and stirred for additional $30 \mathrm{~min}$. The resulting precipitate was filtered, washed with water, and passed through a $1-\mathrm{cm}$ silica gel plug using neat ethyl acetate to remove any unwanted insoluble particles. After solvent removal, the resulting solid was crystallized with methanol to yield crystalline $\mathbf{2}$ in good yield.

4(3H)-Quinazolinone (2a). This was obtained from 1a in $89 \%$ yield as crystalline solid; mp: $214{ }^{\circ} \mathrm{C}$ (Lit. $\left.215^{\circ} \mathrm{C}\right){ }^{14}$; IR $\left(v_{\max }, \mathrm{cm}^{-1}\right): 3134,1695,1601 ;{ }^{1} \mathrm{H}$ NMR $\left(500 \mathrm{MHz}, \mathrm{DMSO}-d_{6}\right): \delta 7.50$ $(\mathrm{dt}, 1 \mathrm{H}, J=8.5,1.0 \mathrm{~Hz}), 7.67(\mathrm{~d}, 1 \mathrm{H}, J=8.5 \mathrm{~Hz}), 7.81(\mathrm{dt}, 1 \mathrm{H}, J=8.5,1.5 \mathrm{~Hz}), 8.09(\mathrm{~s}, 1 \mathrm{H})$, $8.13(\mathrm{dd}, 1 \mathrm{H}, J=8.5,1.5 \mathrm{~Hz}), 12.24$ (br s, $1 \mathrm{H}) ;{ }^{13} \mathrm{C}$ NMR $\left(75 \mathrm{MHz}, \mathrm{DMSO}-d_{6}\right): \delta 122.5,125.7$, 126.6, 127.1, 134.2, 145.2, 148.5, 160.6.

7-Benzyloxy-6-methoxy-4(3H)-quinazolinone (2b). This was obtained from $\mathbf{1 b}$ in $87 \%$ yield as crystalline solid; mp: $258{ }^{\circ} \mathrm{C}$; IR $\left(v_{\max }, \mathrm{cm}^{-1}\right)$ : 2909, 1639, 1607; ${ }^{1} \mathrm{H}$ NMR $(500 \mathrm{MHz}$, DMSO$\left.d_{6}\right): \delta 3.95(\mathrm{~s}, 3 \mathrm{H}), 5.29(\mathrm{~s}, 2 \mathrm{H}), 7.24(\mathrm{~s}, 1 \mathrm{H}), 7.36(\mathrm{t}, 1 \mathrm{H}, J=7.5 \mathrm{~Hz}), 7.43(\mathrm{t}, 2 \mathrm{H}, J=7.5 \mathrm{~Hz})$, 7.49 (t, 3H, $J=7.5 \mathrm{~Hz}), 8.01(\mathrm{~s}, 1 \mathrm{H}), 12.19$ (br s, $1 \mathrm{H}) ;{ }^{13} \mathrm{C}$ NMR $\left(75 \mathrm{MHz}, \mathrm{DMSO}-d_{6}\right): \delta 55.7$, $70.0,105.1,109.3,115.7,127.9,128.1,128.5,136.3,143.8,144.6,148.7,153.3,160.1$.

6-Benzyloxy-7-methoxy-4(3H)-quinazolinone (2c). This was obtained from 1c in $83 \%$ yield as crystalline solid; mp: $252{ }^{\circ} \mathrm{C}$; IR $\left(v_{\max }, \mathrm{cm}^{-1}\right): 2911,1671,1610 ;{ }^{1} \mathrm{H}$ NMR $(500 \mathrm{MHz}$, DMSO$\left.d_{6}\right): \delta 3.97(\mathrm{~s}, 3 \mathrm{H}), 5.24(\mathrm{~s}, 2 \mathrm{H}), 7.18(\mathrm{~s}, 1 \mathrm{H}), 7.38(\mathrm{t}, 1 \mathrm{H}, J=7.0 \mathrm{~Hz}), 7.40(\mathrm{t}, 2 \mathrm{H}, J=7.0 \mathrm{~Hz})$, $7.45(\mathrm{~d}, 2 \mathrm{H}, J=7.0 \mathrm{~Hz}), 7.54(\mathrm{~s}, 1 \mathrm{H}), 7.98(\mathrm{~s}, 1 \mathrm{H}), 12.21(\mathrm{br} \mathrm{s}, 1 \mathrm{H}) ;{ }^{13} \mathrm{C}$ NMR $(75 \mathrm{MHz}, \mathrm{DMSO}-$ $\left.d_{6}\right): \delta 56.0,69.9,106.5,108.2,115.5,127.8,127.9,128.4,136.5,143.9,145.0,147.4,154.7$, 160.0 .

6,7-Dimethoxy-4(3H)-quinazolinone (2d). This was obtained from $1 \mathrm{~d}$ in $78 \%$ yield as crystalline solid; mp: $262{ }^{\circ} \mathrm{C}$ (Lit. $\left.264{ }^{\circ} \mathrm{C}\right){ }^{14}$; IR $\left(v_{\max }, \mathrm{cm}^{-1}\right): 2922,1674,1615 ;{ }^{1} \mathrm{H}$ NMR $(500$ MHz, DMSO- $\left.d_{6}\right): \delta 3.86(\mathrm{~s}, 3 \mathrm{H}), 3.90(\mathrm{~s}, 3 \mathrm{H}), 7.13(\mathrm{~s}, 1 \mathrm{H}), 7.44(\mathrm{~s}, 1 \mathrm{H}), 7.98(\mathrm{~s}, 1 \mathrm{H}), 12.19$ (br 
s, $1 \mathrm{H}) ;{ }^{13} \mathrm{C}$ NMR $\left(75 \mathrm{MHz}\right.$, DMSO- $\left.d_{6}\right): \delta 55.6,55.9,104.8,107.9,115.5,143.7,144.7,148.4$, 154.3, 159.9.

6,8-Dimethoxy-4(3H)-quinazolinone (2e). This was obtained from $1 \mathrm{e}$ in $71 \%$ yield as crystalline solid; mp: $281^{\circ} \mathrm{C}$ (Lit. $280-282{ }^{\circ} \mathrm{C}$ ) ${ }^{14}$; IR $\left(v_{\max }, \mathrm{cm}^{-1}\right): 2937,1667,1607 ;{ }^{1} \mathrm{H}$ NMR (500 MHz, DMSO- $\left.d_{6}\right): \delta 3.85$ (s, 3H), 3.87 (s, 3H), 6.93 (d, 1H, $J=3.0 \mathrm{~Hz}$ ), 7.07 (d, 1H, $J=3.0$ $\mathrm{Hz}), 7.91(\mathrm{~s}, 1 \mathrm{H}), 12.28(\mathrm{br} \mathrm{s}, 1 \mathrm{H}) ;{ }^{13} \mathrm{C}$ NMR $\left(75 \mathrm{MHz}, \mathrm{DMSO}-d_{6}\right): \delta 55.5,56.0,96.5,104.9$, $123.9,134.8,141.5,155.6,158.1,160.2$.

5,6,7-Trimethoxy-4(3H)-quinazolinone (2f). This was obtained from $\mathbf{1 f}$ in $75 \%$ yield as crystalline solid; mp: $229^{\circ} \mathrm{C}$ (Lit. $\left.231^{\circ} \mathrm{C}\right)^{12 b}$; IR $\left(v_{\max }, \mathrm{cm}^{-1}\right): 2838,1674,1599 ;{ }^{1} \mathrm{H}$ NMR $(500$ MHz, DMSO- $\left.d_{6}\right): \delta 3.81(\mathrm{~s}, 3 \mathrm{H}), 3.86(\mathrm{~s}, 3 \mathrm{H}), 3.91(\mathrm{~s}, 3 \mathrm{H}), 7.42(\mathrm{~s}, 1 \mathrm{H}), 8.01(\mathrm{~s}, 1 \mathrm{H}), 12.21(\mathrm{br}$ s, $1 \mathrm{H}) ;{ }^{13} \mathrm{C}$ NMR $\left(75 \mathrm{MHz}\right.$, DMSO- $\left.d_{6}\right): \delta 55.9,60.8,61.8,101.1,118.6,138.3,142.7,146.9$, $147.5,151.9,159.9$.

6-Chloro-4(3H)-quinazolinone (2g). This was obtained from $\mathbf{1 g}$ in $79 \%$ yield as crystalline solid; mp: $264{ }^{\circ} \mathrm{C}$ (Lit. $\left.265-267{ }^{\circ} \mathrm{C}\right)^{14}$; IR $\left(v_{\max }, \mathrm{cm}^{-1}\right): 2847,1679,1604 ;{ }^{1} \mathrm{H}$ NMR $(500 \mathrm{MHz}$, DMSO- $\left.d_{6}\right): \delta 7.69$ (d, $\left.1 \mathrm{H}, J=8.5 \mathrm{~Hz}\right), 7.84(\mathrm{dd}, 1 \mathrm{H}, J=8.5,2.5 \mathrm{~Hz}), 8.05(\mathrm{~d}, 1 \mathrm{H}, J=2.5 \mathrm{~Hz})$, $8.12(\mathrm{~s}, 1 \mathrm{H}), 12.42$ (br s. $1 \mathrm{H}) ;{ }^{13} \mathrm{C}$ NMR $\left(75 \mathrm{MHz}, \mathrm{DMSO}-d_{6}\right): \delta 123.7,124.7,129.4,130.9$, 134.3, 145.8, 147.3, 159.6 .

6-Thiomethoxy-4(3H)-quinazolinone (2h). This was obtained from $\mathbf{1 h}$ in $73 \%$ yield as crystalline solid; mp: $252{ }^{\circ} \mathrm{C}$ (Lit. $203-204{ }^{\circ} \mathrm{C}$ ) ${ }^{14}$; IR $\left(v_{\max }, \mathrm{cm}^{-1}\right): 2850,1682,1605 ;{ }^{1} \mathrm{H}$ NMR $\left(500 \mathrm{MHz}, \mathrm{DMSO}-d_{6}\right): \delta 3.35(\mathrm{~s}, 3 \mathrm{H}), 7.70(\mathrm{~d}, 1 \mathrm{H}, J=8.5 \mathrm{~Hz}), 7.84(\mathrm{dd}, 1 \mathrm{H}, J=8.5,2.5 \mathrm{~Hz}$ ), $8.06(\mathrm{~d}, 1 \mathrm{H}, J=2.5 \mathrm{~Hz}), 8.13(\mathrm{~s}, 1 \mathrm{H}), 12.51(\mathrm{br} \mathrm{s}, 1 \mathrm{H}) ;{ }^{13} \mathrm{C}$ NMR $\left(75 \mathrm{MHz}\right.$, DMSO- $\left.d_{6}\right): \delta 40.1$, $124.4,125.4,130.1,131.7,135.1,146.5,148.2,160.4$.

3-Methyl-4(3H)-quinazolinone (3a). A mixture of $1.0 \mathrm{mmol}$ of starting material (2-nitrobenzoic acid, methyl 2-nitrobenzoate, 2-nitrobenzamide, or 2-nitrocyanobenzene) and $\mathrm{N}$ methylformamide $(1.5 \mathrm{~mL}, 25 \mathrm{mmol})$ was heated at $150{ }^{\circ} \mathrm{C}$ in the presence of indium (III) chloride $(0.22 \mathrm{~g}, 1.0 \mathrm{mmol})$ and monitored by TLC. After the completion of the reaction (average time: $10 \mathrm{~h}$ ), the mixture was poured into ice-cold water $(10 \mathrm{~mL})$ and EtOAc $(10 \mathrm{~mL})$, the organic layer was separated, and the aqueous phase was further extracted with EtOAc. The combined organic extracts were washed with brine, dried over $\mathrm{MgSO}_{4}$, and filtered. The solvent was evaporated in vacuo and the remaining solid was passed through a silica gel column (EtOAc/hexanes, 1:1) to yield 3a as white solid, mp: $103{ }^{\circ} \mathrm{C}$ (Lit. $\left.105{ }^{\circ} \mathrm{C}\right)^{21}$; IR $\left(v_{\max }, \mathrm{cm}^{-1}\right)$ : 2923, 1665, 1608; ${ }^{1} \mathrm{H}$ NMR (500 MHz, DMSO- $d_{6}$ ): $\delta 3.49$ (s, $\left.3 \mathrm{H}\right), 7.54(\mathrm{t}, 1 \mathrm{H}, J=7.5 \mathrm{~Hz}$ ), 7.68 $(\mathrm{d}, 1 \mathrm{H}, J=7.5 \mathrm{~Hz}), 7.81(\mathrm{t}, 1 \mathrm{H}, J=7.5 \mathrm{~Hz}), 8.16(\mathrm{~d}, 1 \mathrm{H}, J=7.5 \mathrm{~Hz}), 8.37(\mathrm{~s}, 1 \mathrm{H}) ;{ }^{13} \mathrm{C}$ NMR $(75$ MHz, DMSO- $\left.d_{6}\right): \delta 33.6,121.3,125.7,126.8,126.9,133.9,147.9,148.3,160.5$.

\section{Acknowledgements}

We are thankful to the NIGMS (S06 GM08194), which provided funds for some equipment used in these studies. MQ was supported by funds from the NIGMS (MARC-U*STAR GM 07717). 
We also like to thank Dr. Terrill Smith and Mr. Mark Penick for their valuable suggestions on this manuscript.

\section{References and Notes}

1. Himmelsbach, F.; Langkopf, E.; Jung, B.; Blech, S.; Solca, F. U.S. Patent 6403 580, 2002; Chem. Abstr. 2002, 136, 216716.

2. (a) Traxler P. M. Expert Opinion on Therapeutic Patents 1997, 7, 571-588. (b) Traxler P. M. Ibid. 1998, 8, 1599-1625.

3. (a) Bridges, A. J. Chem. Rev. 2001, 101, 2541. (b) Morin, M. J. Oncogene 2000, 19, 6574.

4. Wakeling, A. E. In Inhibitors of Protein Kinases and Protein Phosphatases - Handbook of Experimental Pharmacology; Vol. 167; Pinna, L. A.; Cohen, P. T. W., Eds.; SpringerVerlag: Berlin, Germany, 2005; pp 433-450.

5. (a) Collins, I.; Workman, P. Curr. Signal Transduc. Ther. 2006, 1, 13. (b) Grünwald, V.; Hidalgo, M. J. Natl. Cancer Inst. 2003, 95, 852. (c) Denny, W. A. Farmaco 2001, 56, 51. (d) Wakeling, A. E.; Barker, A. J.; Davies, D. H.; Brown, D. S.; Green, L. R.; Cartlidge, S. A.; Woodburn, J. R. Breast Cancer Res. Treat. 1996, 38, 67.

6. (a) Wakeling, A. E. Endocr. Relat. Cancer 2005, 12, S183. (b) Wedge, S. R.; Kendrew, J.; Hennequin, L. F.; Valentine, P. J.; Barry, S. T.; Brave, S. R.; Smith, N. R.; James, N. H.; Dukes, M.; Curwen, J. O.; Chester, R.; Jackson, J. A.; Boffey, S. J.; Kilburn, L. L.; Barnett, S.; Richmond, G. H. P.; Wadsworth, P. F.; Walker, M.; Bigley, A. L.; Taylor, S. T.; Cooper, L.; Beck, S.; Jürgensmeier, J. M.; Ogilvie, D. J. Cancer Res. 2005, 65, 4389. (c) Rich, J. N.; Reardon, D. A.; Peery, T.; Dowell, J. M.; Quinn, J. A.; Penne, K. L.; Wikstrand, C. J.; van Duyn, L. B.; Dancey, J. E.; McLendon, R. E.; Kao, J. C.; Stenzel, T. T.; Rasheed, B. K. A.; Tourt-Uhlig, S. E.; Herndon, J. E., II; Vredenburgh, J. J.; Sampson, J. H.; Friedman, A. H.; Bigner, D. D.; Friedman, H. S. J. Clin. Oncol. 2004, 22, 133. (d) Xia, W.; Mullin, R. J.; Keith, B. R.; Liu, L.-H.; Ma, H.; Rusnak, D. W.; Owens, G.; Alligood, K. J.; Spector, N. L. Oncogene 2002, 21, 6255. (e) Wedge, S. R.; Ogilvie, D. J.; Dukes, M.; Kendrew, J.; Chester, R.; Jackson, J. A.; Boffey, S. J.; Valentine, P. J.; Curwen, J. O.; Musgrove, H. L.; Graham, G. A.; Hughes, G. D.; Thomas, A. P.; Stokes, E. S. E.; Curry, B.; Richmond, G. H. P.; Wadsworth, P. F.; Bigley, A. L.; Hennequin, L. F. Cancer Res. 2002, 62, 4645.

7. (a) Bridges, A. J.; Zhou, H.; Cody, D. R.; Rewcastle, G. W.; McMichael, A.; Showalter, H. D. H.; Fry, D. W.; Kraker, A. J.; Denny, W. A. J. Med. Chem. 1996, 39, 267. (b) Fry, D. W.; Kraker, A. J.; McMichael, A.; Ambroso, L. A.; Nelson, J. M.; Leopold, W. R.; Connors, R. W.; Bridges, A. J. Science 1994, 265, 1093.

8. Herget, T.; Freitag, M.; Morbitzer, M.; Kupfer, R.; Stamminger, T.; Marschall, M. Antimicrob. Agents Chemother. 2004, 48, 4154.

9. Bartroli, J.; Turmo, E.; Algueró, M.; Boncompte, E.; Vericat, M. L.; Conte, L.; Ramis, J.; Merlos, M.; García-Rafanell, J.; Forn, J. J. Med. Chem. 1998, 41, 1869. 
10. Alagarsamy, V.; Rajasolomon, V.; Meena, R.; Ramseshu, K. V. Biol. Pharm. Bull. 2005, 28, 1091.

11. (a) von Niementowski, S. J. Prakt. Chem. 1895, 51, 564. (b) Hisano, T. Org. Prep. Proced. Int. 1973, 5, 145. (c) Katrizky, A. R.; Rees, C. W.; Scriven, E. F. V. Comprehensive Heterocyclic Chemistry II, Pergamon Press: Oxford, United Kindom, 1996. (d) Armarego, W. L. F. Adv. Heterocycl. Chem. 1979, 24, 1.

12. For example, (a) a reductive cyclocondensation has been reported en route to related diaza heterocycles incorporating sulphonamide unit: Restrepo, J.; Perez, Y.; Salazar, J.; Charris, J.; Arvelo, F.; Lopez, S. E. Heterocycl. Commun. 2006, 12, 341. (b) microwave has been applied in place of thermal Niementowski cyclization: Alexandre, F.-R.; Berecibar, A.; Besson, T. Tetrahedron Lett. 2002, 43, 3911.

13. Matsuno, K; Ushiki, J; Seishi, T; Ichimura, M; Giese, N. A.; Yu, J.-C.; Takahashi, S; Oda, S; Nomoto, Y J. Med. Chem. 2003, 46, 4910.

14. LeMahieu, R. A.; Carson, M.; Nazon, W. C.; Parrish, D. R.; Welton, A. F.; Baruth, H. W.; Yaremko, B. J. Med. Chem. 1983, 26, 420.

15. Sathornsumetee, S.; Rich, J. N. Drugs of Today 2006, 42, 657.

16. Wedge, S. R.; Ogilvie, D. J.; Dukes, M.; Kendrew, J.; Curwen, J. O.; Hennequin, L. F.; Thomas, A. P.; Stokes, E. S. E.; Curry, B.; Richmond, G. H. P.; Wadsworth, P. F. Cancer Res. 2000, 60, 970.

17. Wakeling, A. E.; Guy, S. P.; Woodburn, J. R.; Ashton, S. E.; Curry, B. J.; Barker, A. J.; Gibson, K. H. Cancer Res. 2002, 62, 5749.

18. For transition metal complex-catalyzed reductive heterocyclization see: Akazome, M.; Kondo, T.; Watanabe, Y. J. Org. Chem. 1993, 58, 310. (b) Akazome, M.; Yamamoto, J.; Kondo, T.; Watanabe, Y. J. Organometallic Chem. 1995, 494, 229.

19. (a) Liu, X.; Lu, S. J. Molecular Catalysis A: Chemical 2004, 212, 127. (b) Miyata, T.; Kondo, K.; Murai, S.; Hirashima, T.; Sonoda, N. Angew. Chem. 1980, 92, 1040.

20. (a) Yasuda, K. Nippon Kagaku Zasshi 1967, 88, 749; Chem. Abstr. 1967, 69, 10027. (b) Harada, K. Nature 1967, 214, 479. (c) Kakumoto, T.; Saito, K.; Imamura, A. J. Phys. Chem. 1985, 89, 2286.

21. Bogert, M. T.; Geiger, G. A. J. Am. Chem. Soc. 1912, 34, 524. 